\title{
Quick Fix GPS technology highlights risk to dugongs moving between protected areas
}

\author{
Daniel R. Zeh ${ }^{1,2, *}$, Michelle R. Heupel ${ }^{1,2}$, Mark Hamann ${ }^{2}$, Colin J. Limpus ${ }^{3}$, \\ Helene Marsh ${ }^{1,2}$

\begin{abstract}
${ }^{1}$ AIMS@JCU, Australian Institute of Marine Science, Townsville, Queensland 4810, Australia
${ }^{2}$ College of Marine and Environmental Sciences, James Cook University, Townsville, Queensland 4811, Australia

${ }^{3}$ Aquatic Threatened Species Unit, Department of Environment and Heritage Protection, 41 Boggo Rd., Dutton Park, Queensland 4102, Australia
\end{abstract}

\begin{abstract}
Incidental capture in fishing gear is the most serious threat to the survival of many species of marine mammals. Fisheries closures developed to protect marine mammals have tended to concentrate on areas of high marine mammal density. Movement corridors have generally been less protected because they are often unknown and difficult to detect. Seagrass meadows in Moreton and Hervey Bays in south-eastern Queensland support significant populations of dugongs Dugong dugon. Pedigree analysis based on genetic and ancillary biological data indicates that there is substantial movement of dugongs between these bays, which are separated by open surf coasts where dugongs are occasionally caught in inshore shark nets set for the protection of bathers. This bycatch suggests that the dugong movement corridor between Moreton and Hervey Bays is close to the coast, a hypothesis not confirmed by nearly $30 \mathrm{yr}$ of dugong satellite tracking using platform transmitter terminal (PTT) technology. Twenty-nine dugongs were captured in seagrass habitats on the eastern banks of Moreton Bay in 2012-2014 and were fitted with Quick Fix GPS and acoustic transmitters. One animal was captured and tracked twice. Four dugongs were tracked moving from Moreton Bay to Hervey Bay covering distances of 278$338 \mathrm{~km}$ over $5-9 \mathrm{~d}_{i} 1$ dugong made the return journey. Three of the 4 animals travelled along and very close to the coast; the exact track of the fourth animal is uncertain. These results suggest that dugongs would benefit from netting closures that extend beyond seagrass meadows.
\end{abstract}

KEY WORDS: Dugong $\cdot$ Fishery closures $\cdot$ Acoustic $\cdot$ Satellite $\cdot$ Telemetry $\cdot$ Quick Fix GPS

\section{INTRODUCTION}

Incidental capture in fishing gear is the most serious threat to the survival of many species of marine mammals (Reeves et al. 2005, Read et al. 2006, Read 2008, Lascelles et al. 2014). Fisheries closures to protect marine mammals have tended to concentrate on areas of high marine mammal density (Fernandes et al. 2005, Rojas-Bracho et al. 2006, Dobbs et al. 2008, Rayment et al. 2010, Slooten \& Dawson 2010). The conservation of habitats encompassing the extent of a species' movement is an essential component of ecological management (Hooker et al. 2011, Las-

\footnotetext{
${ }^{*}$ Corresponding author: daniel.zeh@my.jcu.edu.au
}

celles et al. 2014); yet, movement corridors may be less adequately protected than high density areas (Corrigan et al. 2014) because they are often unknown (Hyrenbach et al. 2000) or variable (Grüss et al. 2011, Marsh et al. 2011, Lascelles et al. 2014). The necessary spatial information about distribution and movements of species of concern is typically difficult and costly to obtain (Grech et al. 2011).

In south-eastern Queensland, Australia, Moreton Bay (Preen 1992, 1995, Marsh et al. 1999, Lanyon 2003, Grech et al. 2011) and Hervey Bay (Preen \& Marsh 1995, Marsh et al. 1999, Grech et al. 2011) support nationally significant populations of dugongs

() The authors 2016. Open Access under Creative Commons by Attribution Licence. Use, distribution and reproduction are unrestricted. Authors and original publication must be credited. 
Dugong dugon. Large multiple-use marine parks have been established in both bays. The Moreton Bay Marine Park (area: $3400 \mathrm{~km}^{2}$ ) encompasses the entire bay and adjacent waters and includes no-take, limited activity and Go Slow zones in areas recognised as critical habitats for dugongs. The Great Sandy Marine Park (area: $5800 \mathrm{~km}^{2}$ ), which includes Hervey Bay, Great Sandy Strait, Tin Can Bay Inlet and the waters off the east coast of Fraser Island seaward to 3 nautical miles includes similar no-take, limited activity and Go Slow zones. In addition, Hervey Bay includes a Dugong Protection Area of $1703 \mathrm{~km}^{2}$ (Marsh et al. 2000) which was established in January 1998 via a Fisheries Amendment Regulation (No. 11, 1977) under the Fisheries Act, 1994. Gill and mesh netting practices have been modified in this area to reduce the risk of dugong bycatch.

Moreton and Hervey Bay marine parks are separated by $>200 \mathrm{~km}$ with extensive open surf coast, including the Sunshine Coast and Rainbow Beach which are very different environs from the typical dugong seagrass habitats in the bays. Cope et al. (2015) confirmed substantial dugong movements between Moreton and Hervey Bays using pedigree analysis based on genetic and ancillary biological data. Approximately $30 \%$ of assigned parents had at least 1 offspring found in a different location, implying recent movement of the parent or offspring (Cope et al. 2015). Dugongs are occasionally caught in the shark nets set for the protection of bathers along the Sunshine Coast and Rainbow Beach (Marsh et al. 1999, 2005, Meager et al. 2013), suggesting that the area close to the coast may act as a dugong movement corridor.

Dugongs do not undertake seasonal migrations. Their movements are individualistic (Sheppard et al. 2006, Marsh et al. 2011) and include long-distance movements up to $560 \mathrm{~km}$ (Sheppard et al. 2006). Twenty percent of the 70 dugongs satellite-tracked by Sheppard et al. (2006) moved 100-560 km, but none were detected moving between Moreton and Hervey Bays despite $>10$ dugongs being satellitetagged in each of those locations. Thus, Cope et al.'s (2015) pedigree analysis suggested more movement between locations than detected through repeated direct sampling of individuals (Seddon et al. 2014), genetic analysis of population structure (Sneddon et al. 2014) or telemetry (Sheppard et al. 2006).

Despite nearly $30 \mathrm{yr}$ of satellite tracking, dugong movement corridors have proven difficult to map, presumably because the tethered satellite transmitter is dragged under the water while the animal is swimming (Marsh \& Rathbun 1990, Sheppard et al.
2006). Standard high-accuracy GPS-based locations can only be obtained when the transmitter's antenna surfaces for at least $20 \mathrm{~s}$ (Tomkiewicz et al. 2010). Systems with Quick Fix Pseudoranging (QFP) have been designed to reduce the time required to obtain a GPS fix when tracking marine mammals and sea turtles (Tomkiewicz et al. 2010). Within $5 \mathrm{~s}$ of surfacing, QFP systems can collect and transmit all the information necessary to fix the GPS position via post-processing at a later time using Telonics Data Converter software (Telonics Inc. 2007) on a standard personal computer. We used this technology to provide information on dugong movement corridors for the first time and discuss the implications of our results for dugong conservation.

\section{MATERIALS AND METHODS}

Dugongs were captured opportunistically in seagrass habitats in Moreton Bay (Fig. 1) in 2012, 2013 and 2014 using the rodeo method developed by Marsh \& Rathbun (1990) and refined by Lanyon et al. (2006).

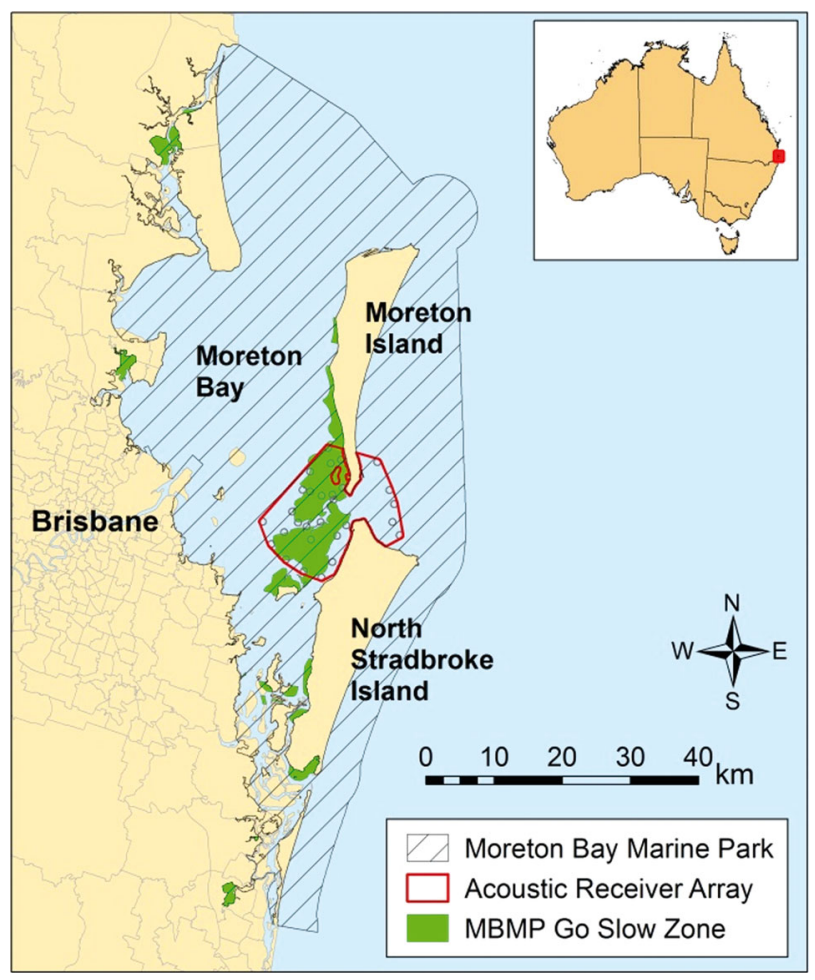

Fig. 1. Location of Moreton Bay Marine Park, Queensland, Australia, showing the Go Slow Zone covering critical seagrass habitats and the location of the acoustic receiver array. Dugongs Dugong dugon were captured and tagged within the Go Slow Zone which contains seagrass habitat critical to their survival in Moreton Bay 
For each dugong, sex was noted, total body length was measured $(\mathrm{cm})$ in a straight line from snout to fluke notch and a titanium ID tag was attached as standard protocol (Limpus 1992). An ARGOS GPS transmitter with QFP technology (Gen 4 Marine Unit, Telonics) was attached via a $3 \mathrm{~m}$ tether to a padded tailstock harness developed by Marsh \& Rathbun (1990) and modified in 2013 based on the design used for tracking manatees (J. Powell pers. comm.). The harness design incorporated a weak link, which enabled the harness to release if the tether snagged, and a metal corrodible link that over several months would release the harness and tether with assembly tracking equipment intact. An acoustic transmitter (V16TP, Vemco) was incorporated in the tailstock harness.

The ARGOS GPS (QFP) transmitters were programmed to emit each dugong's GPS position hourly. Location data for each dugong were compiled daily, collected through ARGOS satellites and reported on a website from the time the telemetered dugong was released until a transmitter was detached or stopped transmitting. The specific tag detachment time was determined by the clear difference between the preand post-detachment tracks which enabled accurate estimation of the overall GPS transmitter deployment time and aided in tag equipment recovery. All tracking data were truncated at the estimated detachment date to ensure that calculated activity spaces excluded any potential drift data.

Each acoustic transmitter emitted a unique individual ID code, depth $(\mathrm{m})$ and temperature $\left({ }^{\circ} \mathrm{C}\right)$ at $69 \mathrm{kHz}$ at a pseudo-random interval every $45-90 \mathrm{~s}$. This programming limited signal interference with other deployed transmitters in the same area. Transmitter signals could be detected if a tagged dugong was within $~ 800 \mathrm{~m}$ of an array of 28 acoustic receivers strategically placed in eastern Moreton Bay. The detection range was calibrated based on data collected from moored sentinel tags in the study area (M. Heupel unpubl. data). The selection of the array site was supported by large numbers of dugongs previously reported for the area (Preen 1992, 1995, Marsh et al. 1999, Lanyon 2003, Grech et al. 2011).

\section{Data filtering}

GPS data binning and filtering were accomplished using a custom R (R Core Team 2014) script based in part on previous speed-filters (McConnell et al. 1992, Flamm et al. 2001, Austin et al. 2003, Freitas et al. 2008). GPS data filters included filtering to (1) eliminate duplicate times or duplicate consecutive loca- tions, (2) retain only 'successful' and 'resolved QFD' data (i.e. the most accurate and most reliable data) and (3) remove spurious consecutive data points that resulted in calculated speeds $>20 \mathrm{~km} \mathrm{~h}^{-1}$ for maximum burst swimming speed (Marsh et al. 1981, 2011) or calculated speeds $>10 \mathrm{~km} \mathrm{~h}^{-1}$ for maximum cruising speed (Marsh et al. 1981, 2011). Data locations which plotted on land were deleted. GPS data used to analyse movements between Moreton and Hervey Bays were filtered but not binned in order to capture all available locations.

Acoustic data were processed to provide locations for individual dugongs using a centre-of-activity approach (Simpfendorfer et al. 2002) based on a weighted mean of the number of detections at each receiver within each time period. The time period was set to $3 \mathrm{~h}$ for all individuals.

\section{Tracking duration}

Complete GPS datasets were used to calculate the duration of satellite tag deployment for each tag. Successive data points signifying movement between the 2 bays were identified by the relatively large distances $($ mean $=42 \mathrm{~km}, \mathrm{SD}=38$, median $=23$ ) between the GPS data points. Travel start dates were determined from the data location immediately preceding bay-to-bay movement. Similarly, travel end dates were determined by choosing the data location immediately following the bay-to-bay movement. The number of days between tagging, the travel start date, the number of travel locations, the average speed $(\mathrm{km}$ $\mathrm{h}^{-1}$ ) and the distance travelled $(\mathrm{km})$ were calculated using the GPS locations. The average distance to the coastline $(\mathrm{km})$ from each GPS travel location was derived using the Near tool in the ArcGIS 10.2 Proximity Toolbox (ESRI 2014). GPS data for each dugong were used to calculate the percentage of time when (1) locations were within the marine park boundaries for travelling and non-travelling dugongs and (2) travel locations were within $5 \mathrm{~km}$ of the coastline. The duration of acoustic tag deployment was calculated from the data recorded by the individual acoustic receivers summarised by transmitter ID.

Minimum convex polygons (MCP) were calculated to estimate the maximum extent of movements for individuals. Space use was refined by calculating 50 and $95 \%$ kernel utilisation distributions (KUDs). The $50 \%$ KUD represented the core use area of an individual, while the $95 \%$ KUD represented the extent of home range movement, comparable in scale to $\mathrm{MCP}$ estimates. 


\section{RESULTS}

Twenty-nine dugongs were tagged in Moreton Bay in July-September 2012, July 2013 and April-May 2014; 1 dugong was tagged in both 2013 and 2014. The 29 dugongs were of mixed ages, based on body lengths as defined by Lanyon et al. (2010): adults ( 7 females, 10 males, body length $>260 \mathrm{~cm}$ ), sub-adults (5 females, 4 males, body length 241-260 cm) and small sub-adults ( 3 males, body length $\leq 240 \mathrm{~cm}$ ). Four dugongs ( 1 adult male, 1 sub-adult male and 2 adult females) were tracked from Moreton Bay to Hervey Bay. One of these adult females was GPS tracked travelling to Hervey Bay in July 2013 and returning to Moreton Bay in August 2013. This individual was also detected by acoustic receivers in Moreton Bay in May and June 2014.

For 3 dugongs, $52 \%$ of the between-bay locations (32 locations) were within $5 \mathrm{~km}$ of the coast and $46 \%$ (28 locations) were within the boundaries of either the Moreton Bay or Great Sandy Marine Parks. Only 2 GPS location points were available for 1 dugong (PTT ID 112595): a location in Moreton Bay Marine Park immediately after it was released and a location in the Great Sandy Marine Park (suggesting possible speedy movements between the 2 locations with the transmitter underwater). The only available satellite points were 11 unfiltered ARGOS satellite locations,
1 of Location Class A and 10 of Location Class B, which confirmed PTT ID 112595's trip north but suggested sea travel away from the coast. Location Classes A and B have no accuracy estimation (ARGOS User's Manual @2011) so that these positions must be considered approximate. A further 579 GPS data locations were obtained from PTT ID 112595's transmitter in Hervey Bay over 10 wk. The spatial pattern of these locations indicated that the transmitter was still on the dugong.

All of the dugongs began their movements north shortly after tagging $(1,2,5,12 \mathrm{~d})$ and took nearly a week $(5,6,7,9 \mathrm{~d}$ north and $5 \mathrm{~d}$ south) to travel between the bays (Table 1). The number of GPS travel locations logged varied from 2 to 38 (mean = $12.2 \pm 14.6 \mathrm{SD}$ ). The duration of GPS tracking ranged from 35 to $147 \mathrm{~d}$ (mean $=86.5 \pm 45.2$ ). The number of GPS locations per day ranged from 8.3 to 13.8 $($ mean $=11.1 \pm 3.6)$. The overall average for the combined total of 346 GPS tracking days was 9.7 detections per day (Table 1). The total number of tracking days as detected by the acoustic array in Moreton Bay varied from 1 to $53($ mean $=17.5 \pm 24.1)$, and the number of locations per day ranged from 2.4 to 21 (mean $=9.6 \pm 9.0$ ).

Individual dugongs' activity spaces were variable. Minimum convex polygons ranged from 2.3 to $242.6 \mathrm{~km}^{2}$ in Moreton Bay Marine Park $(\mathrm{n}=4)$ and

Table 1. Tracking metrics for dugongs Dugong dugon that moved between Moreton and Hervey (HB) Bays, separated into groups (A) all days tracked and (B) travel days only. For each dugong except PTT ID 112597, the number of travel points was low, an indication of relatively fast travel speed dragging the transmitter underwater. Thirty-eight GPS travel points were recorded from PTT ID 112597 which had the longest trip duration. N: northward; S: southward; -: not applicable

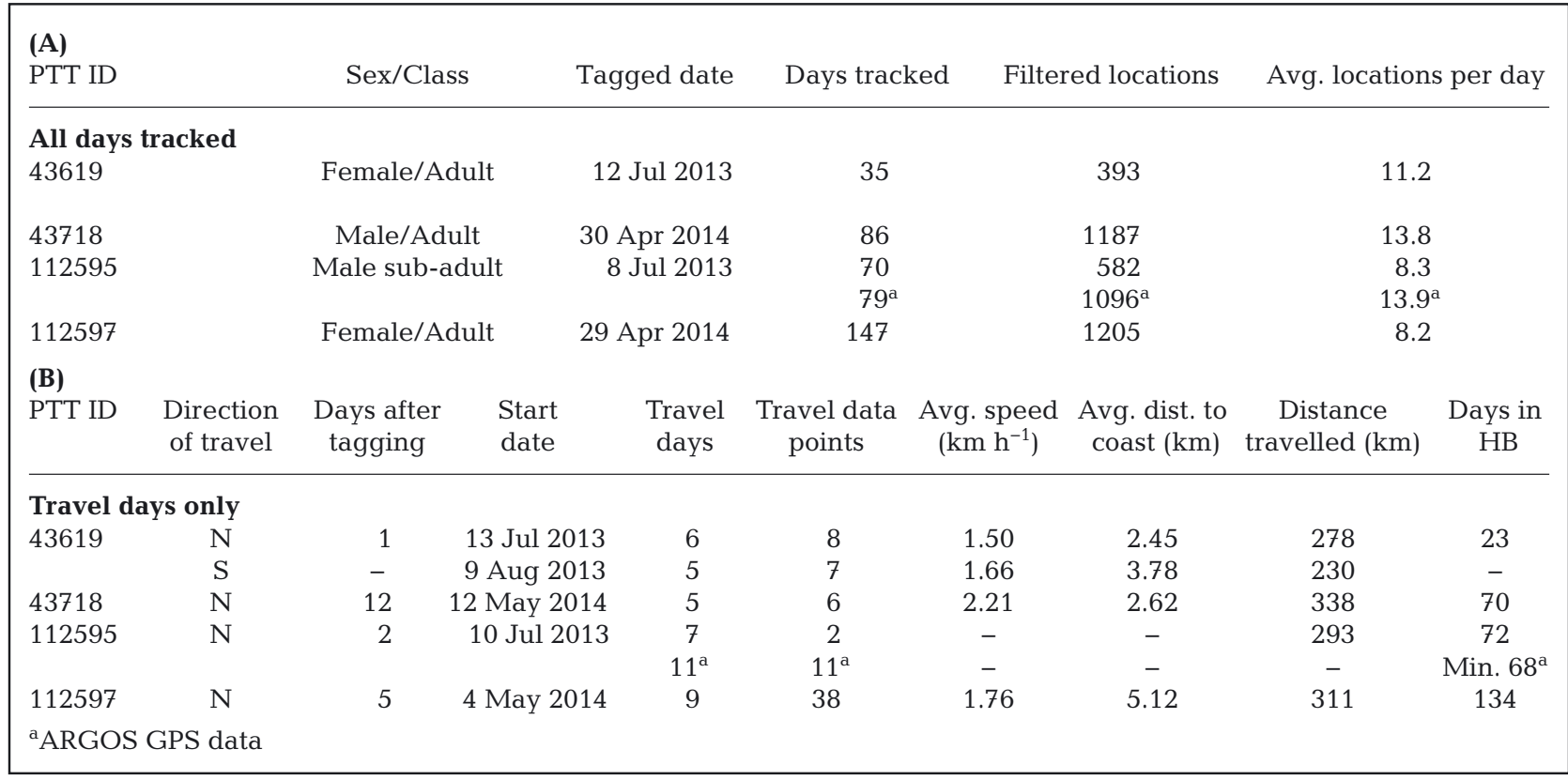


87.2 to $2143.6 \mathrm{~km}^{2}$ in the Great Sandy Marine Park (n = 4). In the Moreton Bay Marine Park, $95 \%$ KUDs ranged from 101.7 to $260.0 \mathrm{~km}^{2}(\mathrm{n}=2)$ and $50 \%$ KUDs ranged from 4.9 to $60.9 \mathrm{~km}^{2}$ ( $\mathrm{n}=2$ ). In the Great Sandy Marine Park, 95\% KUDs ranged from 15.8 to $1116.9 \mathrm{~km}^{2}(\mathrm{n}=4)$ and $50 \%$ KUDs ranged from 2.3 to $182.1 \mathrm{~km}^{2}(\mathrm{n}=4)$ (Table 2$)$.

\section{DISCUSSION}

GPS technology enabled us to determine the routes of 3 dugongs that travelled 278-338 $\mathrm{km}$ from Moreton Bay to Hervey Bay and the return journey of one of these animals. All individuals stayed within $5 \mathrm{~km}$ of the coast during their journeys. GPS locations received from a fourth dugong in both Moreton and Hervey bays revealed movement between these bays, but no GPS locations were recorded enroute. Unreliable ARGOS locations suggested that this dugong may have taken an ocean route. These 4 dugongs represented $14 \%$ of the 29 dugongs we captured in Moreton Bay and satellite tracked.

The 4 dugongs that moved between bays left Moreton Bay within 1, 2, 5 and $12 \mathrm{~d}$ of capture, suggesting possible flight responses for at least 2 of the animals. Gredzens et al. (2014) reported an animal undertaking a $90 \mathrm{~km}$ movement $2 \mathrm{~d}$ after it was captured and tagged. Sheppard et al. (2006) recorded that 14 of 70 radiotracked dugongs made macro-scale movements (>100 km) 18.1 to $513 \mathrm{~d}$ $($ mean $=89.9 \mathrm{~d})$ after they were tagged. The mean time between tagging and initial large-scale movement for the 70 animals tracked varied (mean $=33.4 \pm 10.3 \mathrm{~d}$, min. $=0 \mathrm{~d}$, max. $=271.6 \mathrm{~d})$, clearly indicating that not all acro-scale movements documented through satellite tracking can be explained by flight responses.

All the macro-scale movements of satellite-tracked dugongs reported to date have been rapid and directed (e.g. Sheppard et al. 2006, Gredzens et al. 2014), and our results are consistent with these observations. These movements involved adult and subadult animals of both sexes. In contrast, the pedigree data based on a much larger sample size suggest that male dugongs move between populations more than females do (Cope et al. 2015). Our sample size was too small to further investigate sex differences in the likelihood of making macro-scale movements.

The activity spaces of our tracked dugongs varied by individual (Table 2, a result consistent with the literature (Table 3). Gredzens et al. (2014) suggested that the size of an individual's activity space may be dependent upon the area of available seagrass habitat, but this hypothesis does not explain the differences we observed. The seagrass areas in Hervey Bay are larger than those in Moreton Bay (Hervey Bay seagrass $2480 \mathrm{~km}^{2}$ vs. Moreton Bay seagrass $384 \mathrm{~km}^{2}$; McKenzie 2014), but the data sets of location points for Moreton Bay were smaller than those in Hervey Bay (see Table 1), so no attempt was made to formally test the hypothesis in this paper.

The home ranges for each animal we tracked confirmed that the eastern banks in the Moreton Bay Marine Park and Hervey Bay in the Great Sandy Marine Park were the centres of the dugongs' activity spaces. As explained above, these 2 marine parks are

Table 2. Minimum convex polygons (MCPs) and kernel utilization distributions (KUDs) in Moreton Bay (MB) and Hervey Bay (HB) for each of the tagged dugongs that moved between the 2 bays. -: not applicable

\begin{tabular}{|lcrrccc|}
\hline $\begin{array}{l}\text { PTT } \\
\text { ID }\end{array}$ & Location & $\begin{array}{c}\text { Data } \\
\text { points }\end{array}$ & $\begin{array}{r}\text { MCP } \\
\left(\mathrm{km}^{2}\right)\end{array}$ & $\begin{array}{c}95 \% \text { KUD } \\
\left(\mathrm{km}^{2}\right)\end{array}$ & $\begin{array}{c}50 \% \text { KUD } \\
\left(\mathrm{km}^{2}\right)\end{array}$ & $\begin{array}{c}95 \% \text { KUD } \\
\text { /MCP }\end{array}$ \\
\hline \multirow{2}{*}{43619} & MB Start & 11 & 83.2 & - & - & - \\
& HB & 330 & 674.0 & 531.3 & 49.2 & 78.8 \\
& MB End & 37 & 19.2 & 18.5 & 4.7 & 96.4 \\
112718 & MB Start & 392 & 242.6 & 101.7 & 4.9 & 41.9 \\
& HB & 789 & 87.2 & 15.8 & 2.3 & 18.1 \\
& MB Start & 3 & 2.3 & - & - & - \\
& HB & 579 & 440.2 & 67.1 & 8.8 & 15.2 \\
& MB Start & 70 & 174.2 & 260.0 & 60.9 & 149.3 \\
& HB & 1097 & 2143.6 & 1116.9 & 182.1 & $52.1 \%$ \\
\hline
\end{tabular}

Table 3. Reported calculated $95 \%$ KUD activity spaces of dugongs vary widely by location

\begin{tabular}{|lccc|}
\hline Location & $\begin{array}{c}\text { KUD range } \\
\left(\mathrm{km}^{2}\right)\end{array}$ & $\begin{array}{c}\text { No. of } \\
\text { dugongs }\end{array}$ & Source \\
\hline Lease Islands, Indonesia & $1.65-127.9$ & 4 & De Iongh et al. (1998) \\
Shoalwater Bay, Qld & $15.9-1444.5$ & 5 & Gredzens et al. (2014) \\
Torres Strait & $264.3-1269.2$ & 6 & Gredzens et al. (2014) \\
10 locations, Qld & $0.5-733.0$ & 50 & Sheppard et al. (2006) \\
Moreton Bay, Qld & $16.7-68.3$ & 13 & Zeh et al. (2015) \\
Moreton Bay, Qld & $67.1-531.3$ & 2 & Present paper \\
Hervey Bay, Qld & $15.8-1116.9$ & 4 & Present paper \\
\hline
\end{tabular}


established dugong hotspots with significant numbers of dugongs, and some areas have been zoned to protect them (Preen 1992, Lanyon 2003, Grech et al. 2011, Marsh et al. 2011, Sobtzick et al. 2012). However, there is no such protection along the $\sim 200 \mathrm{~km}$ of open coast between the northern boundary of More-
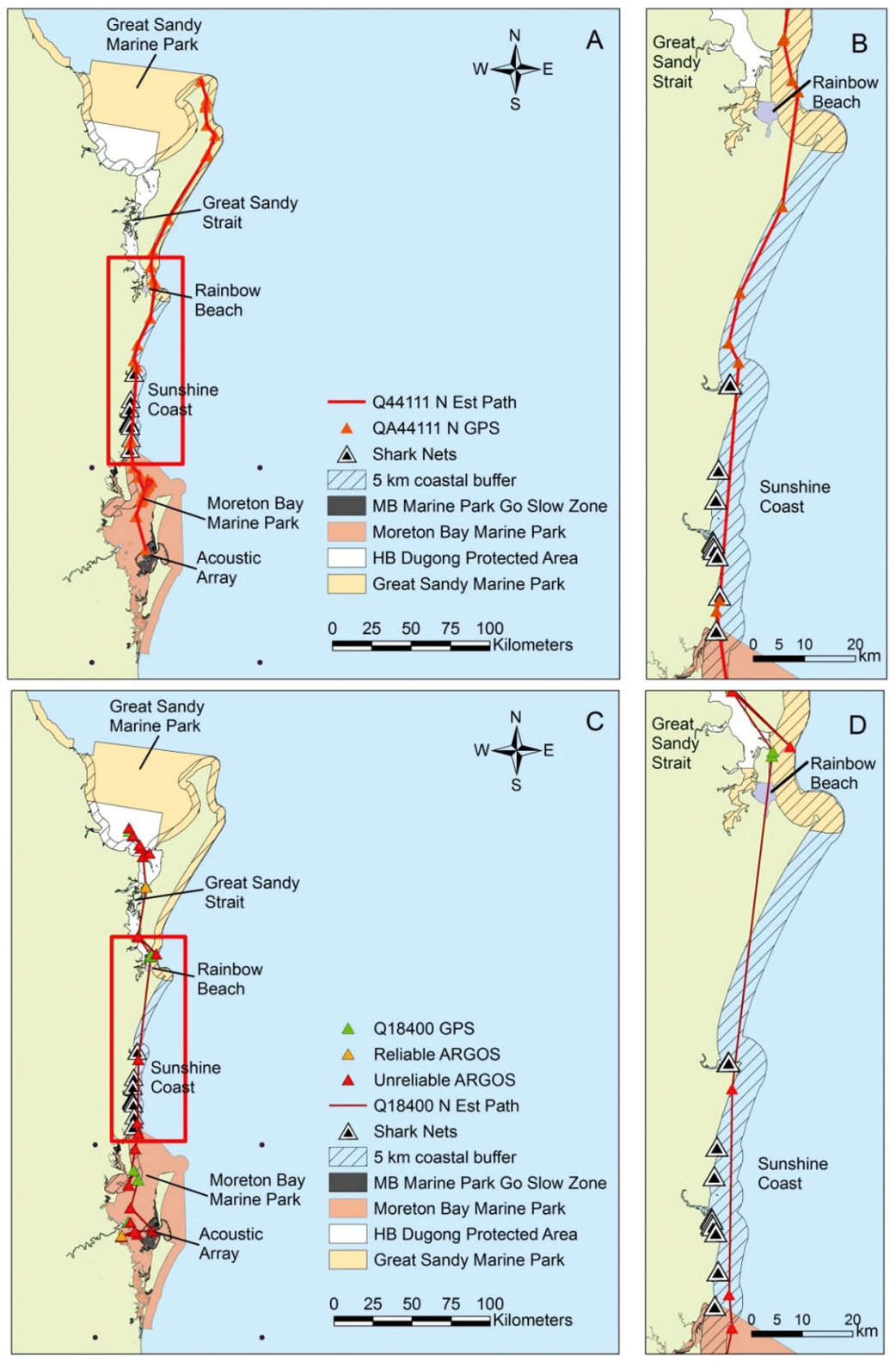

Fig. 2. Paths created from GPS locations of 2 dugongs that moved between Moreton Bay Marine Park and Great Sandy Marine Park. (A,B) Movements of Dugong Q44111; (C,D) movements of Dugong Q18400. All coastal movement data points are within $5 \mathrm{~km}$ of the coast (within the $5 \mathrm{~km}$ buffer) which contains the Sunshine Coast and Rainbow Beach shark nets. The data for Dugong Q18400 included few GPS locations (8), and the ARGOS locations are also shown. The precision of reliable ARGOS locations (Location Classes 1,2 , or 3 ) is $<1 \mathrm{~km}$; the error of unreliable ARGOS locations (Classes 0 , A, or $\mathrm{B}$ error) is unknown. The track for Dugong Q44111 was created from 38 GPS points. MB: Moreton Bay; HB: Hervey Bay ton Bay Marine Park and Rainbow Beach in the southern portion of Great Sandy Marine Park. Shark nets for the protection of bathers are located immediately offshore of several Sunshine Coast beaches and Rainbow Beach, and 39 dugongs were recorded drowned in shark nets from 1989 to 2011 (catch data obtained from the Queensland Shark Control Program, Queensland Department of Agriculture and Fisheries). Shark nets are uniquely located, typically within $5 \mathrm{~km}$ of the coast depending on the shape of the bay, and are deployed in 3,4 , or $6 \mathrm{~m}$ depths as appropriate per water depth (QDAF 2016). The directed movement of 3 tracked dugongs through this region (Fig. 2) confirms longshore movements within the shark protection net areas, and demonstrates that some individuals successfully avoid entanglement. Three of the 4 dugongs we tracked stayed within 5 $\mathrm{km}$ of the open coast. Dugongs tracked by Sheppard et al. (2006) stayed mostly within $7 \mathrm{~km}$ of the coast, but were often found up to $20 \mathrm{~km}$ away from the coast. How much these differences reflect the lack of precision of the earlier technologies used by Sheppard et al. (2006) is not known.

The Great Barrier Reef World Heritage Area spans some $14^{\circ}$ latitude from just north of Hervey Bay to Cape York. An extensive series of Dugong Protection Areas and marine park zoning areas have been established to protect relatively high-density dugong areas in this World Heritage Area (Marsh 2000, Dobbs et al. 2008, Grech $\&$ Marsh 2008). Mesh netting has been banned from areas close to major headlands to protect dugongs travelling between bays (GBRMPA 1983). The results presented here suggest that this protection may be insufficient for dugongs moving along stretches of coast between seagrass beds. However, more dugong tracking studies are needed to confirm this hypothesis.

Marine protected areas (MPAs) are typically designed to protect areas of high biodiversity or species of significant conservation concern. The areas used by megafauna such as marine 
mammals are typically larger than those afforded by individual MPAs, although MPAs can reduce the risk of human-induced harm (Marsh et al. 2011). The frequency of travel between patches of suitable habitat varies greatly among individuals and species (Hilty et al. 2006). Conserving suitable and adequate habitat to maintain connectivity is an essential component of ecological management (Hooker et al. 2011, Lascelles et al. 2014), yet movement corridors are often unknown (Hyrenbach et al. 2000) or vary for natural reasons (Grüss et al. 2011, Marsh et al. 2011, Lascelles et al. 2014), making conservation in these areas difficult. Protection of important habitats within movement corridors can be less adequate than that of high-density foraging areas (Corrigan et al. 2014), due to the difficulty and costliness of defining the necessary spatial information (Grech et al. 2011).

This study is an example of how modern technology can reveal previously unknown movement corridors. Some 87 species of marine mammals are listed under the Convention for Migratory Species (CMS 2015). The application of GPS/satellite technology to discover and record the movement corridors of such species promises to be a powerful tool to inform their conservation.

Acknowledgements. This research was funded by an Australian Marine Mammal Centre grant to H.M. and M.R.H. D.R.Z. was supported by funding from AIMS@JCU and the College of Marine and Environmental Sciences, JCU. This research was conducted under the following permits: Marine Parks QS2013/MAN213, QDEHP WISP69649711 and James Cook University Animal Ethics Permit A1683. Some of the acoustic receivers utilised in this research were part of the Australian Animal Tagging and Monitoring System (AATAMS) facility of the Integrated Marine Observing System competitive receiver pool. The authors thank the AATAMS staff for their support. The CSIRO Division of Marine Research provided all acoustic receivers in 2012 and 6 in 2013. The authors also thank the many people who helped with field efforts, particularly C. Cleguer, F. de Faria, N. FitzSimmons, C. Gredzens, C. Heatherington, J. Meager, S. Preston, J. Smith and K. Townsend. M. Flint provided veterinary oversight for the catching of dugongs in 2013, and J. Powell assisted with the design of the 2013 tether attachment. The authors thank the staff and volunteers of the Moreton Bay Marine Research Station for assistance with the deployment, maintenance and downloading of acoustic receivers, and C. Roelfsema for detailed seagrass data.

\section{LITERATURE CITED}

> Austin D, McMillan JI, Bowen WD (2003) A three-stage algorithm for filtering erroneous ARGOS satellite locations. Mar Mamm Sci 19:371-383

CMS (Conservation of Migrator Species) (2015) Appendices I and II of the Convention on the Conservation of Migra- tory Species of Wild Animals (as amended by the Conference of the Parties in 1985, 1988, 1991, 1994, 1997, 1999, 2002, 2005, 2008, 2011 and 2014). Effective: 8 February 2015. www.cms.int/en/species (accessed 15 May 2015)

> Cope RC, Pollett PK, Lanyon JM, Seddon JM (2015) Indirect detection of genetic dispersal (movement and breeding events) through pedigree analysis of dugong populations in southern Queensland, Australia. Biol Conserv 181: 91-101

> Corrigan CM, Ardron JA, Comeros-Raynal MT, Hoyt E, Notarbartolo Di Sciara G, Carpenter KE (2014) Developing important marine mammal area criteria: learning from ecologically or biologically significant areas and key biodiversity areas. Aquat Conserv 24:166-183

> De Iongh HH, Langeveld P, van der Wal M (1998) Movement and home ranges of dugongs around the Lease Islands, East Indonesia. Mar Ecol (Berl) 19:179-193

> Dobbs K, Fernandes L, Slegers S, Jago B and others (2008) Incorporating dugong habitats into the marine protected area design for the Great Barrier Reef Marine Park, Queensland, Australia. Ocean Coast Manage 51: 368-375

ESRI (Environmental Systems Research Institute) (2014) ArcGIS Desktop: Release 102. ESRI, Redlands, CA

Fernandes L, Day J, Lewis A, Slegers S and others (2005) Establishing representative no-take areas in the Great Barrier Reef: large-scale implementation of theory on marine protected areas. Conserv Biol 19:1733-1744

Flamm R, Ward L, Weigle B (2001) Applying a variableshape spatial filter to map relative abundance of manatees (Trichechus manatus latirostris). Landscape Ecol 16: $279-288$

> Freitas C, Lydersen C, Fedak MA, Kovacs KM (2008) A simple new algorithm to filter marine mammal Argos locations. Mar Mamm Sci 24:315-325

GBRMPA (Great Barrier Reef Marine Park Authority) (1983) Great Barrier Reef Marine Park Regulations 1983. In: Federal Register of Legislative Instruments F2014C 01241 Statutory Rules No. 262, 1983, as amended: includes amendments up to: SLI No. 153, 2014; Book Statutory Rules No. 262, 1983, as amended: includes amendments up to: SLI No. 153, 2014. The Office of Parliamentary Counsel, Canberra

Grech A, Marsh H (2008) Rapid assessment of risks to a mobile marine mammal in an ecosystem-scale marine protected area. Conserv Biol 22:711-720

> Grech A, Sheppard J, Marsh H (2011) Informing species conservation at multiple scales using data collected for marine mammal stock assessments. PLoS ONE 6:e17993

> Gredzens C, Marsh H, Fuentes MMPB, Limpus C, Shimada T, Hamann M (2014) Satellite tracking of sympatric marine megafauna can inform the biological basis for species co-management. PLoS ONE 9:e98944

Grüss A, Kaplan DM, Guénette S, Roberts CM, Botsford LW (2011) Consequences of adult and small sub-adult movement for marine protected areas. Biol Conserv 144: 692-702

Hilty JA, Lidicker WZ Jr, Merenlender AM (2006) Corridor ecology: the science and practice of linking landscapes for biodiversity conservation. Island Press, Washington, DC

> Hooker SK, Cañadas A, Hyrenbach KD, Corrigan C, Polovina JJ, Reeves RR (2011) Making protected area networks effective for marine top predators. Endang Species Res 13:203-218

Hyrenbach KD, Forney KA, Dayton PK (2000) Marine pro- 
tected areas and ocean basin management. Aquat Conserv 10:437-458

Lanyon JM (2003) Distribution and abundance of dugongs in Moreton Bay, Queensland, Australia. Wildl Res 30: 397-409

Lanyon JM, Slade RW, Sneath HL, Broderick D and others (2006) A method for capturing dugongs (Dugong dugon) in open water. Aquat Mamm 32:196-201

Lanyon JM, Sneath HL, Long T, Bonde RK (2010) Physiological response of wild dugongs (Dugong dugon) to out-of-water sampling for health assessment. Aquat Mamm 36:46-58

Lascelles B, Notarbartolo Di Sciara G, Agardy T, Cuttelod A and others (2014) Migratory marine species: their status, threats and conservation management needs. Aquat Conserv 24:111-127

Limpus CJ (1992) Estimation of tag loss in marine turtle research. Wildl Res 19:457-469

Marsh H (2000) Evaluating management initiatives aimed at reducing the mortality of dugongs in gill and mesh nets in the Great Barrier Reef World Heritage Area. Mar Mamm Sci 16:684-694

Marsh H, Rathbun GB (1990) Development and application of conventional and satellite radio tracking techniques for studying dugong movements and habitat use. Aust Wildl Res 17:83-100

Marsh H, Gardner BR, Heinsohn GE (1981) Present-day hunting and distribution of dugongs in the Wellesley Islands (Queensland): implications for conservation. Biol Conserv 19:255-267

Marsh H, Eros C, Corkeron P, Breen B (1999) A conservation strategy for dugongs: implications of Australian research. Mar Freshw Res 50:979-990

Marsh H, De'ath G, Gribble N, Lane B (2000) Four decades of decline in dugong numbers off the urban coast of Queensland: evidence from the Queensland Shark Control Program. Great Barrier Reef Marine Park Authority, Townsville, Queensland

Marsh H, De'ath G, Gribble N, Lane B (2005) Historical marine population estimates: triggers or targets for conservation? The dugong case study. Ecol Appl 15:481-492

Marsh H, O'Shea TJ, Reynolds JE III (2011) Ecology and conservation of the Sirena: dugongs and manatees. Cambridge University Press, New York, NY

McConnell BJ, Chambers C, Fedak MA (1992) Foraging ecology of southern elephant seals in relation to the bathymetry and productivity of the Southern Ocean. Antarct Sci 4:393-398

McKenzie LJ (2014) Composite of coastal seagrass meadows in Queensland, Australia-November 1984 to June 2010 Supplement to: McKenzie, Len J, Yoshida, Rudolf L, Grech A, Coles R (2010) Queensland seagrasses. Status 2010-Torres Strait and East Coast. Fisheries Queensland (DEEDI), Cairns

Meager JJ, Limpus CJ, Sumpton W (2013) A review of the population dynamics of dugongs in southern Queensland: 1830-2012. Queensland Government Department of Environment and Heritage Protection, Brisbane

Preen A (1992) Interactions between dugongs and seagrasses in a subtropical environment. PhD thesis, James Cook University, Townsville

> Preen A (1995) Impacts of dugong foraging on seagrass habitats: observational and experimental evidence for cultivation grazing. Mar Ecol Prog Ser 124:201-213
Preen A, Marsh H (1995) Response of dugongs to large-scale loss of sea grass from Hervey Bay, Queensland, Australia. Oceanogr Liter Rev 43:507-519

QDAF (Queensland Department of Agriculture and Fisheries) (2016) Queensland Department of Agriculture and Fisheries Shark Control Program. https://www.daf.qld. gov.au/fisheries/services/shark-control-program/sharkcontrol-equipment-and-locations (accessed 20 January 2016)

R Core Team (2014) R: a language and environment for statistical computing. R Foundation for Statistical Computing, Vienna. www.R-project.org

Rayment W, Dawson S, Slooten E (2010) Seasonal changes in distribution of Hector's dolphin at Banks Peninsula, New Zealand: implications for protected area design. Aquat Conserv 20:106-116

$>$ Read AJ (2008) The looming crisis: interactions between marine mammals and fisheries. J Mammal 89:541-548

Read AJ, Drinker P, Northridge S (2006) Bycatch of marine mammals in U.S. and global fisheries. Conserv Biol 20: 163-169

Reeves RR, Berggren P, Crespo EA, Gales N and others (2005) Global priorities for reduction of cetacean bycatch. World Wildlife Fund, Washington, DC. http:// cetaceanbycatch.org/pr.2005.06.09.cfm (accessed 5 April 2015)

Rojas-Bracho L, Reeves RR, Jaramillo-Legorreta A (2006) Conservation of the vaquita Phocoena sinus. Mammal Rev 36:179-216

Seddon JM, Ovenden JR, Sneath HL, Broderick D, Dudgeon CL, Lanyon JM (2014) Fine scale population structure of dugongs (Dugong dugon) implies low gene flow along the southern Queensland coastline. Conserv Genet 15: 1381-1392

Sheppard JK, Preen AR, Marsh H, Lawler IR, Whiting SD, Jones RE (2006) Movement heterogeneity of dugongs, Dugong dugon (Müller), over large spatial scales. J Exp Mar Biol Ecol 334:64-83

Simpfendorfer CA, Heupel MR, Hueter RE (2002) Estimation of short-term centers of activity from an array of omnidirectional hydrophones and its use in studying animal movements. Can J Fish Aquat Sci 59:23-32

> Slooten E, Dawson SM (2010) Assessing the effectiveness of conservation management decisions: likely effects of new protection measures for Hector's dolphin (Cephalorhynchus hectori). Aquat Conserv 20:334-347

Sobtzick S, Hagihara R, Grech A, Marsh H (2012) Aerial survey of the urban coast of Queensland to evaluate the response of the dugong population to the widespread effects of the extreme weather events of the summer of 2010-11. In: Final report to the Australian Marine Mammal Centre and the National Environment Research Facility

Telonics Inc. (2007) Telonics Data Converter Version 2.13. Telonics, Mesa, AZ

> Tomkiewicz SM, Fuller MR, Kie JG, Bates KK (2010) Global positioning system and associated technologies in animal behaviour and ecological research. Philos Trans R Soc B 365:2163-2176

- Zeh DR, Heupel MR, Limpus CJ, Hamann M and others (2015) Is acoustic tracking appropriate for air-breathing marine animals? Dugongs as a case study. J Exp Mar Biol Ecol 464:1-10 